\title{
Standard Recipes of Traditional Turkish and Latvian Meals: Similarities and Differences*
}

\author{
Şükran Öktem \\ Baskent University, Ankara, Turkey
}

\author{
Brigita Purina \\ Turiba University, Riga, Latvia
}

\begin{abstract}
One of the elements of attraction in tourism sector is food and beverage. International food habits consist of national food habits in tourism. Preparing standard recipes for traditional food is required in point of the sustainability of cultural food habits. Also, it is important in point of the tourism sector. Similar aspects of food from different cultures and differences can be an attraction factor. This paper explains the development of Turkish and Latvian cuisines through history. In this research, Turkish and Latvian traditional foods have been researched and standard recipes have been organized. As an example, Turkish and Latvian traditional foods have been compared with each other. This paper offers guidelines for developing traditional food recipes as gastronomic tourism product, which can be adapted throughout the region and can be an important element in sustainable tourism projects. In conclusion, some similarities and differences have been observed between them and have been evaluated in terms of the tourism product.
\end{abstract}

Keywords: Turkish cuisine, Latvian cuisine, standard recipes

\section{Introduction}

Nowadays, people while on holiday and travelling are more interested not just in satiating hunger, but also in the cooking traditions that are related to different cultures. The search for new and more interesting products has led to the rediscovery of gastronomy.

Local restaurants, taverns, and bars are the first places where tourists are looking for the new experience. Therefore, it is important to create the menu and prepare meals according to the local traditions and latest trends.

In particular, cultural studies should be done for the sustainability of traditional food and be passed on to future generations. Some tools are available for this purpose and one of these tools is the standard recipe. The purpose of this study is to prepare the standard recipes of some Turkish and Latvian traditional dishes, to reveal their similarities and differences, and to allow the exchange of food culture in tourism business.

\footnotetext{
* This research is a revised and extended version of the proceeding with the title "Standard Recipes of Traditional Turkish and Latvian Meals: Similarities and Differences", whose abstract has been published in the conference proceedings of the 4th Advances in Hospitality and Tourism Marketing and Management Conference, June 25-27, 2014 organized by University of Mauritius and Washington State University.

Şükran Öktem, assistant professor, Dr., Department of Business Administration, Kazan Vocational School, Baskent University. Email: sukran@baskent.edu.tr.

Brigita Purina, lecturer, MBA, Faculty of International Tourism, Turiba University.
} 


\section{Gastronomy and Traditional Cuisine}

There is a rapid growing interest about the ancient peasant food and the regional traditional cuisine associated with a local culture. Tourists like to enjoy native food, particularly items of local or ethnic nature. Gastronomic tourism within the tourism industry is the most popular activity (Kesici, 2012; Şanlıer, 2005).

The literature supports the view that there is a connection between tourism and gastronomy. Gastronomy is becoming an important part of travel and plays an important role in the way tourists experience the destination. There is an indication that some travellers would return to the same destination to savour its unique gastronomy (Hall \& Sharples, 2003).

Traditional cuisine is a part of cultural heritage and a part of gastronomic tourism that popularises and presents country (Timothy \& Boyd, 2003).

Local food traditions are influenced by ancestral customs, history, geography, daily life, religion, and economic and social development of a region (Bober, 1999).

Traditional cuisine refers to particular geographical locations and the products and cooking traditions of these places. Classifying a cuisine according to a geographical location and nation allows people to create convenient categories for understanding food practices (Tannahill, 1989).

Latvian and Turkish cuisines are traditional and at the same time, different recipes and local products give each and every dish its unique taste. Therefore, it is important that information regarding the local dishes, special recipes, and local products be reflected in local restaurants' menus and preserved for the next generations.

\section{Turkish Cuisine}

Turkish cuisine has its origins in the Central Asian food culture. Today, the Turkish people have created the Turkish cuisine being affected by some different cultures, a historical path extending from Asia to Anatolia. These different cultures have contributed to the Turkish cuisine from different aspects like content, health, and taste. Fast-breaking meal, the meals for poor people, feast of the sacrifice, and votive dishes as food samples have an effect on Turkish cuisine by the religion of Islam and Arab cuisine. Especially, Islam has prohibited some foods, e.g., pork (Akman \& Mete, 1998; Beşirli, 2010).

In the beginning, the eating habits of Turks who led a nomadic life have developed based on their life style. Generally, meat, milk, yogurt, consuming nomadic Turkish people, switched to sedentary life which made their food habits different. The nutrition with vegetables has gained importance especially in Mediterranean region of Anatolia (Baysal, Merdol, Başoğlu, Ciğerim, \& Sacır, 2013).

Turkish cuisine is composed of two parts: Ottoman palace cuisine and Turkish regional cuisine. Ottoman palace cuisine is nutritious, delicious, and decorated. Turkish cuisine has emerged according to the local customs, traditions, and economic conditions of Anatolia. Today, Turkish cuisines consist of the dishes that have been made with meat and vegetables. In addition, various spices are used, and buttermilk, fruit juice, and lemonade of beverages are accompanied to dishes. Most dishes are oily and difficult to prepare (Albayrak, 2013). As an example, dolma (stuffed vegetables), sarma (stuffed vine leaves), kebabs, mantı (pasty), and legume dishes prepared with meat like dread beans, chickpea, lentil, and other meat dishes can be mentioned. Generally, rice or bulgur pilaf, seasonal salad or cacik (cucumber-yoghourt) are served with meals. The most preferred drink is buttermilk with meals. Sweet varieties are baklava, sweet pastry, candy, or milk-based desserts. There is a tradition of drinking Turkish coffee after meals, and also, there is an old saying about this tradition: "A cup of coffee has respect of forty years" (Türk \& Şahin, 2004). On special occasions such as Bayram and weddings, traditional dishes are offered and at the end of the meal, after dessert okra meal with lemon is served. 
With the increasing number of working women, difficult but delicious homemade meals have been decreased. Increasingly, homemade meals are losing property because of the lack of natural materials. This case shows that sustainable food is very important as a promotional tool in tourism.

The most important tool to ensure the sustainability of food is the standard recipe. Ten standard recipes have been prepared to underline the characteristics of Turkish dishes (see Tables 1-10).

\section{Turkish Traditional Dishes}

There are various nutritious soups in Turkish cuisine. Especially, Turkish people have tarhana soup in the breakfast. Another nutritious soup is Arabaşı (Arapaşı). A standard soup recipe is given as an example in Table 1.

Table 1

Standard Recipe 1: Arabaşı Soup (Arapaşı)

\begin{tabular}{|c|c|c|c|}
\hline Portion & \multicolumn{3}{|l|}{$4(1$ portion $=1$ bowl $)$} \\
\hline \multirow[t]{2}{*}{ Serving size (raw weight) } & \multicolumn{3}{|l|}{$400 \mathrm{ml}$} \\
\hline & Item & Cost & \\
\hline \multirow{7}{*}{ Ingredients } & 900 gr. chicken or partridge & & \\
\hline & 75 gr. butter or olive oil & & \\
\hline & 20 gr. pepper paste & & \\
\hline & 10 gr. tomato paste & & \\
\hline & 100 gr. flour & & \\
\hline & 5 gr. salt & & \\
\hline & $1 / 2$ lt. water & & \\
\hline & & Total cost & \\
\hline & & Cost per serving & \\
\hline Procedures & \multicolumn{3}{|c|}{$\begin{array}{l}\text { 1. Partridge/chicken is boiled, diddly (thin into pieces). } \\
\text { 2. Use butter/olive oil (individually or together) to heat the saucepan, add flour, and fry the flour until } \\
\text { pink in colour. } \\
\text { 3. Add the tomato and the red pepper paste and also fry three minutes. } \\
\text { 4. Add the chicken broth and water and blend this mixture gradually (the mixture should be taken to } \\
\text { prevent clumping). } \\
\text { 5. Water boils and the meat is added. } \\
\text { 6. The soup is served with lemon juice (Arabaş1 soup is drunk with dough). }\end{array}$} \\
\hline
\end{tabular}

Table 2

Standard Recipe 2: The Dough of the Arabaşı Soup (Arapaşı)

\begin{tabular}{|l|l|l|l|}
\hline Portion & 4 (1 portion = 25 gr.) \\
\hline Serving size (raw weight) & 100 gr. & \multicolumn{2}{|l|}{ Cost } \\
\hline & Item & \\
\hline \multirow{3}{*}{ Ingredients } & 250 gr. flour & & \\
\cline { 2 - 4 } & 5 gr. salt & Total cost & Cost per serving \\
\cline { 2 - 3 } Procedures & $1 / 4$ lt. water & $\begin{array}{l}\text { 1. Water is boiled in a pot. } \\
\text { 2. Half of the boiling water is taken from the pot when it becomes warm, and formed into a thick soup } \\
\text { made with flour (in the form of yoghurt). } \\
\text { 3. Continue to boil the remaining water, add salt into the water, and stir continuously. } \\
\text { 4. The slurry is added to water little by little (the mixture should be taken to prevent clumping). } \\
5 . \text { The mixture is taken from the furnace and poured into a tray, and then allowed to cool in a cold } \\
\text { environment (not put in the refrigerator). } \\
6 . \text { After cooling, is poured inverted another tray (must be paid to the dissolution), which is placed in a } \\
\text { lozenge-shaped serving dish (inverted appear brighter than the surface). }\end{array}$ \\
\hline
\end{tabular}

Note. When the custard cooked more than consistency of dark, adding water can be brought to the desired consistency. 
Meat is the most important part of the Turkish cuisine. Veal, mutton, goat's meat, poultry and lamb are eaten, but especially meat in all its forms such as different-type kebabs, grilled meat on skewers, cutlets, roasts, stews, sausage, and pastrami.

Table 3

Standard Recipe 3: Tantuni (Wrap With Fried Meat)

\begin{tabular}{|c|c|c|c|}
\hline Portion & \multicolumn{3}{|l|}{$4(1$ portion $=2$ wrap $)$} \\
\hline \multirow[t]{2}{*}{ Serving size (raw weight) } & \multicolumn{3}{|l|}{250 gr. } \\
\hline & Item & Cost & \\
\hline \multirow{10}{*}{ Ingredients } & 1 kg. steak & & \\
\hline & 8 tantuni bread & & \\
\hline & 1 onion & & \\
\hline & 4 tomatoes & & \\
\hline & 4 green capsicums & & \\
\hline & A pinch of parsley & & \\
\hline & 20 gr. black pepper & & \\
\hline & 20 gr. chili pepper & & \\
\hline & 1/6 lt. olive oil & & \\
\hline & 5 gr. salt & & \\
\hline & & Total cost & \\
\hline & & Cost per serving & \\
\hline Procedures & \multicolumn{3}{|c|}{$\begin{array}{l}\text { 1. Steak is chopped into very small pieces. } \\
\text { 2. Meat is placed on the edge of the special tantuni pan and cooked at a medium heat. } \\
\text { 3. The meat is fried and olive oil is added into the pan. } \\
\text { 4. The meats are taken to the centre of the pan and stir them occasionally and slowly. } \\
\text { 5. Spices are added to the well-done cooked meat. } \\
\text { 6. Roasting meat, washed and finely chopped previously tomatoes, onions, parsley, green pepper, and } \\
\text { salt are added to the tantuni bread (single or double bread optionally used) and are shaped into rolls. } \\
\text { 7. Tantuni is served with lemon, chopped radishes, fresh and pickle hot pepper. }\end{array}$} \\
\hline
\end{tabular}

Table 4

Standard Recipe 4: Batırlk (Cold Soup)

\begin{tabular}{|c|c|c|c|}
\hline \multirow{3}{*}{\begin{tabular}{|l} 
Portion \\
Serving size (raw weight) \\
\end{tabular}} & \multicolumn{2}{|l|}{4} & \\
\hline & 250 gr. & & \\
\hline & Item & Cost & \\
\hline \multirow{17}{*}{ Ingredients } & 300 gr. peanut & & \\
\hline & 200 gr. sesame & & \\
\hline & 400 gr. fine bulgur & & \\
\hline & 1 medium size onion & & \\
\hline & 10 gr. pepper paste & & \\
\hline & $1.5 \mathrm{~kg}$. tomato & & \\
\hline & 50 gr. dry tomato & & \\
\hline & 1 kg. cucumber & & \\
\hline & 100 gr. green capsicum & & \\
\hline & A pinch of parsley & & \\
\hline & 100 gr. scallion & & \\
\hline & 6 sprigs fresh or 20 gr. (dry) spearmint & & \\
\hline & 6 sprigs fresh or 20 gr. (dry) basil & & \\
\hline & $1 / 2$ cabbage (white) or 10 sprigs (green) & & \\
\hline & 250 gr. (fresh or preserved in brine-desalinated) vine leaves & & \\
\hline & 20 gr. salt & & \\
\hline & 1 1t. water & & \\
\hline & & Total cost & \\
\hline & & Cost per serving & \\
\hline
\end{tabular}


(Table 4 continued)

\begin{tabular}{|c|c|}
\hline Procedures & $\begin{array}{l}\text { 1. Roasted peanuts and sesame seeds are allowed to cool (must be careful not to overheat, and } \\
\text { because of the bounce feature, roasted sesame seeds should be sealed). } \\
\text { 2. Cabbage and connective leaves are boiled in a separate pot (cooking time is different for different } \\
\text { cooking). } \\
\text { 3. A few tomatoes are sliced or grated or minced. } \\
\text { 4. A portion of the cucumber is cut into thin slices, some of them are sliced. } \\
\text { 5. Green sweet peppers are minced. } \\
\text { 6. Parsley, mint, green pepper, green onions and basil are minced (dried mint and dried basil can also } \\
\text { be used). } \\
\text { 7. A portion of boiled cabbage and vine leaves are set aside, and the remainder (very) are } \\
\text { minced. } \\
\text { 8. Peanut and sesame seeds are browned, cooled, and are puréed in a food processor. } \\
\text { 9. One onion is minced, pepper paste is added, a little salt is dusted on the onion and puréed with } \\
\text { hand, and a little more grated tomatoes are added and puréed with hand. } \\
\text { 10. Dügürcük somewhat is softened and parsley, mint, and basil are added and a little more dügürcük } \\
\text { is rubbed. } \\
\text { 11. A glass of lemon juice is added, the mixture a little more is rubbed with hand. } \\
\text { 12. The taste is checked and if the mix is softened, all cucumber, green pepper, and green onion are } \\
\text { added into the mix which is called "köfte" and as small pieces are placed on a plate with cabbage and } \\
\text { leaf. } \\
\text { 13. The remaining portion is gradually diluted and continue rubbing, the consistency should not be } \\
\text { too dry or too liquid. } \\
\text { 14. Chilled water is added during the warmer months, while in winter, the normal water is added. } \\
\text { 15. Lemon juice and salt are added. } \\
\text { 16. The aqueous portion is placed on plates; coarsely-grated cucumbers, tomatoes, and finely-grated } \\
\text { cabbage and leaf are added on it; and batırk is served. } \\
\text { 17. Köfte plate is put on the table, optionally before or after drinking batırik (usually the first), you } \\
\text { can eat köfte. }\end{array}$ \\
\hline
\end{tabular}
Note. Batırık, like Gazpacho, drink cold soup, generally meeting of Türk ladies, is served to guests in their home as a meal option in the past.

\section{Table 5}

Standard Recipe 5: Tavuk Yahni (Chicken Stew)

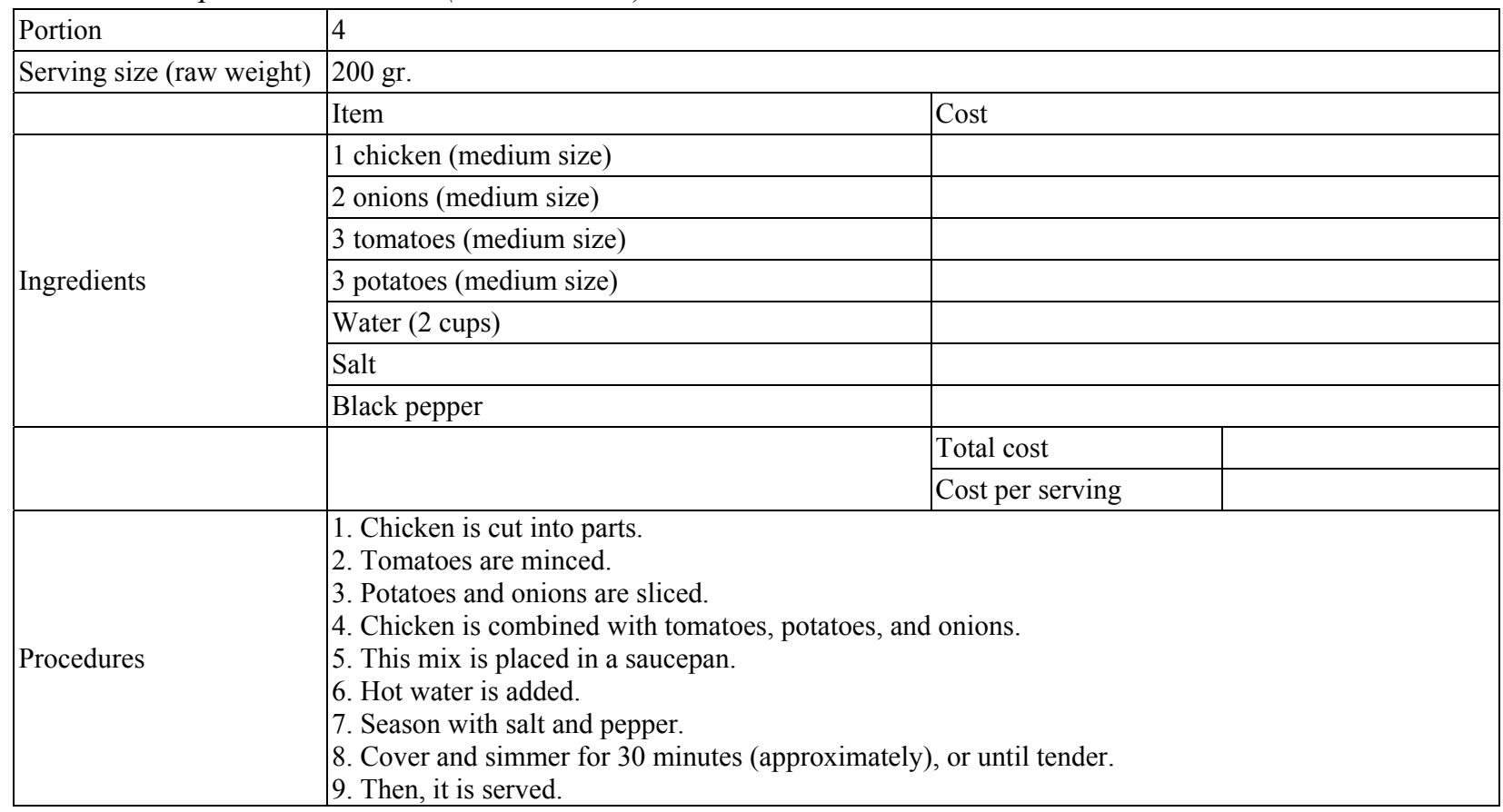


Table 6

Standard Recipe 6: Bastı (Vegetable Stew)

\begin{tabular}{|c|c|c|c|}
\hline Portion & \multicolumn{3}{|l|}{4} \\
\hline \multirow[t]{2}{*}{ Serving size (raw weight) } & \multicolumn{3}{|l|}{200 gr. } \\
\hline & Item & Cost & \\
\hline \multirow{9}{*}{ Ingredients } & 1 middle size red beet & & \\
\hline & $10-15$ pieces of dry prune & & \\
\hline & 100 gr. boiled chickpea & & \\
\hline & 2 pieces of middle size potatoes & & \\
\hline & 2 pieces of middle size onions & & \\
\hline & 50 gr. dried tomato (powdered pounded) & & \\
\hline & 75 gr. butter & & \\
\hline & $1 / 4$ lt. water & & \\
\hline & 5 gr. salt & & \\
\hline & & Total cost & \\
\hline & & Cost per serving & \\
\hline Procedures & \multicolumn{3}{|c|}{$\begin{array}{l}\text { 1. Chop the onions. } \\
\text { 2. Fry the onions until they are pink in color. } \\
\text { 3. Dice the beet, add the dried tomato (powdered pounded), add onion, and then cook. } \\
\text { 4. Add boiled chickpea and potato. } \\
\text { 5. Add boiled water. } \\
\text { 6. Add wetted dry prune and also cook } 10 \text { minutes. }\end{array}$} \\
\hline
\end{tabular}

Note. Bast1 is not consumed too much nowadays, and it is only cooked in the villages from time to time.

\section{Table 7}

Standard Recipe 7: Sarı Kabak Yemeği (Yellow Pumpkin)

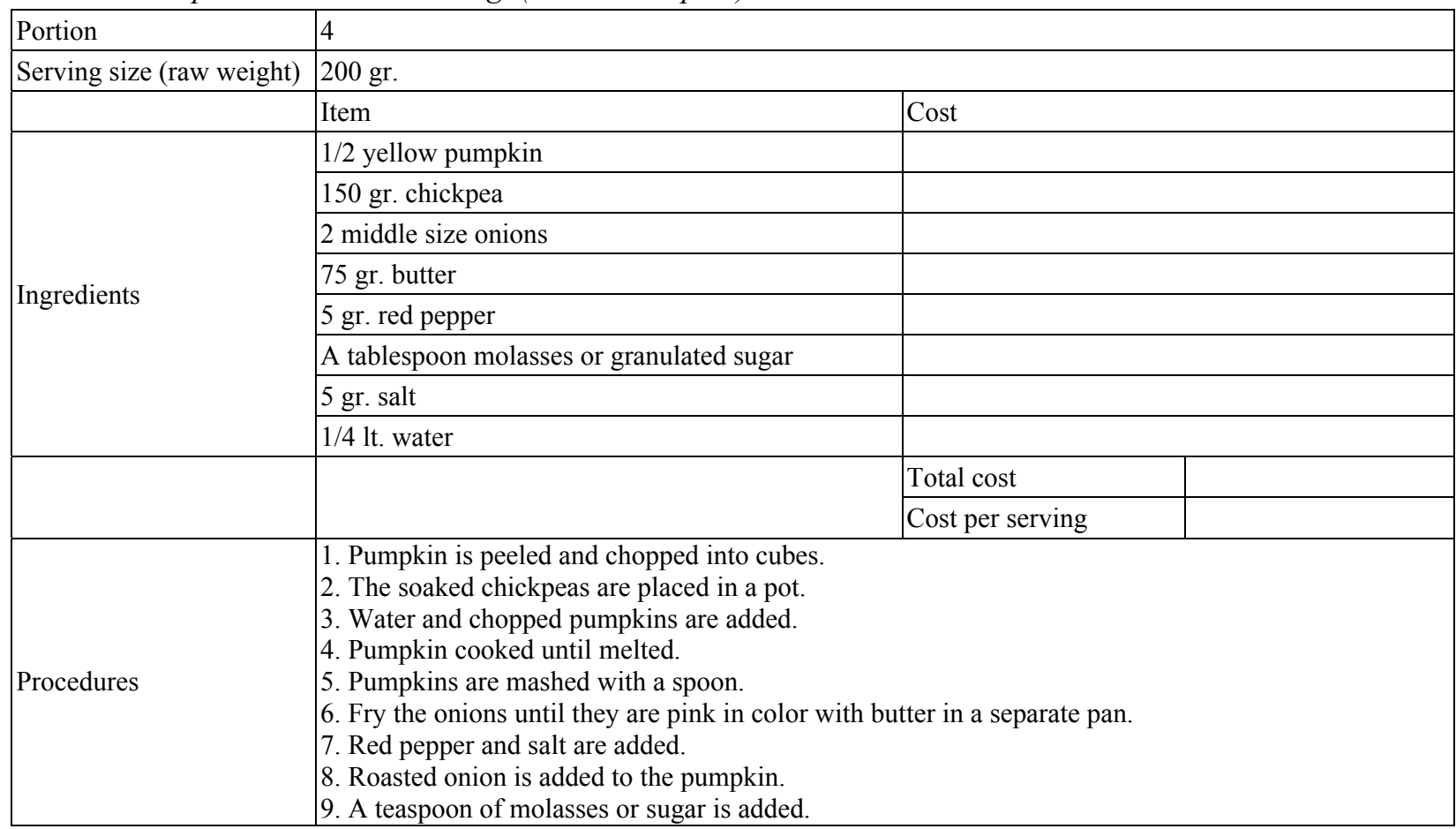


Table 8

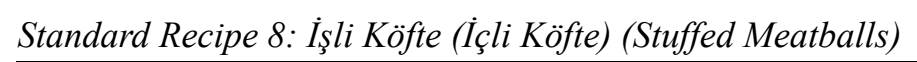

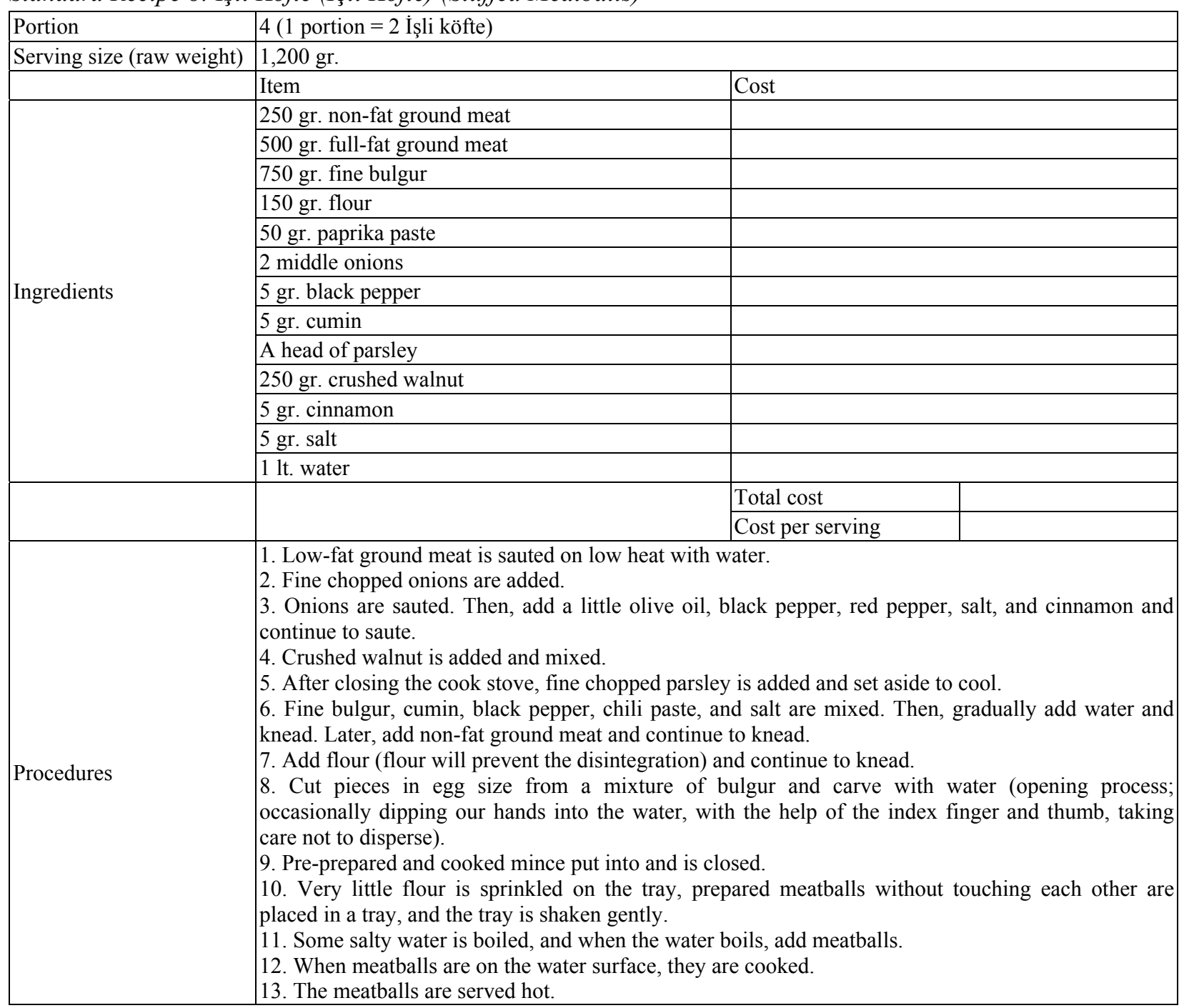

Table 9

Standard Recipe 9: Slyırma (Fresh Cow Pea)

\begin{tabular}{|c|c|c|}
\hline Portion & 4 & \\
\hline \multirow[t]{2}{*}{ Serving size (raw weight) } & 200 gr. & \\
\hline & Item & Cost \\
\hline \multirow{7}{*}{ Ingredients } & 1,000 gr. fresh cow pea & \\
\hline & 2 middle size lemons & \\
\hline & 1 sour pomegranate seed & \\
\hline & 5 gr. salt & \\
\hline & 2 lt. water & \\
\hline & & Total cost \\
\hline & & Cost per serving \\
\hline Procedures & \multicolumn{2}{|c|}{$\begin{array}{l}\text { 1. Fresh cow pea is washed and boiled without peeling. } \\
\text { 2. Water is filtered and taken to a serving platter, and salt is thrown. } \\
\text { 3. Lemon juice and sour pomegranate seeds are added, mixed, and served warm. } \\
\text { 4. Fresh cow pea is eaten without peeling and called "slyırma". }\end{array}$} \\
\hline
\end{tabular}


Table 10

Standard Recipe 10: Ev Makarnasu (Homemade Pasta)

\begin{tabular}{|c|c|c|c|}
\hline Portion & \multicolumn{3}{|l|}{4} \\
\hline \multirow[t]{2}{*}{ Serving size (raw weight) } & \multicolumn{3}{|l|}{200 gr. } \\
\hline & Item & Cost & \\
\hline \multirow{6}{*}{ Ingredients } & 500 gr. flour & & \\
\hline & 1 lt. water & & \\
\hline & 5 gr. salt & & \\
\hline & $5+5$ gr. tomato and pepper paste & & \\
\hline & 75 gr. butter or olive oil & & \\
\hline & 1 middle size onion & & \\
\hline & & Total cost & \\
\hline & & Cost per serving & \\
\hline Procedures & \multicolumn{3}{|c|}{$\begin{array}{l}\text { 1. The dough is kneaded by putting water and salt. } \\
\text { 2. Clean tablecloth is spread, senit (a wooden tool for dough) is put on tablecloth, and the flour is } \\
\text { sprinkled on tablecloth and senit. } \\
\text { 3. A piece of the dough is cut and is put on the senit and is made into rolls manually. } \\
\text { 4. When the rolls are shaped, small pasta is poured into the tablecloth. } \\
\text { 5. Fry the onions until they become pink. } \\
\text { 6. Tomato and pepper paste are added and little more are sauted. } \\
\text { 7. Water is added (for consistency, it would be a consistency between meals with soup consistency is } \\
\text { adjusted according to the amount of water). } \\
\text { 8. When the water is boiled, pasta is thrown into the water and is cooked } 10 \text { or } 15 \text { minutes. } \\
\text { 9. Pasta is served hot. }\end{array}$} \\
\hline
\end{tabular}

\section{Latvian Cuisine}

Over the centuries, various cultural influences from Europe were reflected in Latvia, and these include culinary trends. Germany, Sweden, and USSR have left their imprint on the food traditions of Latvia. During the Soviet occupation, local recipes were suppressed. The meals were poor and the same standard recipes for the limited dishes were used at the eating establishments all around the USSR.

Today, Latvian cuisine can be characterized as a blend of history and traditions. Latvian gastronomic heritage was formed by the merging of experience gained over the centuries, despite 50 years of the Soviet occupation, by the influence of Baltic German cuisine. Over the years, many dishes were inherited and adapted from the Baltic German cuisine and with the passage of time and change in generations, they have been considered traditional. The dishes acquired from the Baltic German cuisine have integrated so deeply that people have, over the years, accepted these dishes as their own - Latvian. Today, these are acknowledged to be a part of the traditional Latvian cuisines irrespective of where they originated (Dumpe, 2009).

In Latvia, many food traditions are closely linked with the changing seasons. The way it is spiced and cooked often reflects the storage needs of the peasant communities of the old days. Food traditionally is with mild flavour without the sharp spices. The most popular traditional herb is dill and the most popular spice is caraway seed. Poppy seeds are popular for cakes and different kinds of bread.

Latvians over the centuries have used a variety of food in their dishes, such as grains (rye, barley, wheat, etc.), legumes (peas, beans, etc.), vegetables (cabbage, carrot, and other vegetables), hemp, wild plants (sorrel, nettle, etc.), dairy products especially kefir, yogurt, fermented milk, sour cream, cottage cheese, etc., as well as meat (pork, lamb weal, chicken, duck) and fish (various types of cooked, salted, smoked, and dried).

The introduction of potatoes and sugar in the first half of the 19th century brought in significant lasting changes in the nutrition of Latvian inhabitants. These over time changed the conception of Latvian food, and 
Latvian eating traditions can be divided into before potatoes and after potatoes. Contemporary Latvian traditional food is unthinkable without potato pancakes, potato dumplings, oven-baked potatoes, mashed potatoes, and various other potato dishes.

Latvians are especially proud of their rye bread that symbolizes more than just food and is connected to different Latvian folk beliefs and customs (Pelude, 2011). Rye bread has been a significant part of Latvian nutrition since ancient times over the generations and is eaten during breakfast, lunch, and supper.

At the end of a meal, very often dessert is served. The Latvian menu includes various desserts such as pudding, various jellies, creams, mousses. Various cakes, biscuits, buns, and various tarts (cottage cheese tart, apple tart, and rhubarb tart) are typical for the region.

To get the necessary information about the Latvian traditional food, 10 books from the period from 1905 till 2011 were analysed. Ten recipes similar of the dishes that are given as examples of Latvian traditional dishes were searched and found in the books of Korta (1905), Suta (1930), Breikse (1935), Silina (1935), Bertina (1937), Strazdina (1969), Masilune and Pasopa (1986), Dumpe (2009), Masilune (2011), and Pelude (2011). Content analyses were used for the data analyses. Based on the available information on the ingredients and quantity of ingredients for the selected dishes, 10 standard recipes were developed according to the common methodology.

\section{Latvian Traditional Dishes}

Among the typical dishes of the region, there are a lot of different soups: milk soup, meat soup, fish soup, vegetable and mushroom soup, and cold soup. Soup is a typical lunch dish. Soups that are on the milk base could be cooked with the different vegetables, noodles, barley, semolina, rice, corn flake, dumplings, herring, peas, and potatoes (Masilune \& Pasopa, 1986; Silina, 1935; Bertina, 1937).

Milk soups are typical for the breakfast. Semolina, rice, and corn flake soups could be served with sugar and cinnamon. Two standard soup recipes are given as examples in Tables 11 and 12.

Table 11

Standard Recipe 11: Pumpkin and Semolina Milk Soup

\begin{tabular}{|c|c|c|}
\hline Portion & \multicolumn{2}{|c|}{$4(1$ portion $=1$ bowl $)$} \\
\hline \multirow[t]{2}{*}{ Serving size (raw weight) } & \multicolumn{2}{|l|}{$200 \mathrm{ml}$} \\
\hline & Item & Cost \\
\hline \multirow{7}{*}{ Ingredients } & $100 \mathrm{~g}$ water & \\
\hline & $700 \mathrm{ml} \mathrm{milk}$ & \\
\hline & $360 \mathrm{~g}$ pumpkin & \\
\hline & 20 g semolina & \\
\hline & $10 \mathrm{~g}$ butter & \\
\hline & 20 g sugar & \\
\hline & $0.2 \mathrm{~g}$ cinnamon & \\
\hline & & Total cost \\
\hline & & Cost per serving \\
\hline Procedures & \multicolumn{2}{|c|}{$\begin{array}{l}\text { 1. Cut the pumpkins into small cubes. } \\
\text { 2. Add water and butter to the pumpkin and cook until tender. } \\
\text { 3. Blend the pumpkins until smooth. } \\
\text { 4. Add milk to the blended pumpkins and cook until the milk is hot. } \\
\text { 5. Stir in semolina and add a pinch of salt and cook for } 5-10 \text { minutes. } \\
\text { 6. Serve hot sprinkled with sugar and cinnamon for the breakfast or late dinner. }\end{array}$} \\
\hline
\end{tabular}


Table 12

Standard Recipe 12: Bean Soup

\begin{tabular}{|c|c|c|c|}
\hline Portion & \multicolumn{3}{|c|}{$4(1$ portion $=1$ bowl $)$} \\
\hline \multirow[t]{2}{*}{ Serving size (raw weight) } & \multicolumn{3}{|c|}{$200 \mathrm{ml}$} \\
\hline & Item & Cost & \\
\hline \multirow{9}{*}{ Ingredients } & $900 \mathrm{ml}$ meat broth & & \\
\hline & $150 \mathrm{~g}$ bean & & \\
\hline & 60 g carrot & & \\
\hline & $10 \mathrm{~g}$ parsley & & \\
\hline & 1 onion & & \\
\hline & $10 \mathrm{~g}$ pearl barley & & \\
\hline & 100 g potato & & \\
\hline & \begin{tabular}{|l|} 
Salt, herbs \\
\end{tabular} & & \\
\hline & $6 \mathrm{~g}$ dill or parsley & & \\
\hline & & Total cost & \\
\hline & & Cost per serving & \\
\hline Procedures & \multicolumn{3}{|c|}{$\begin{array}{l}\text { 1. Pour the water over the dried beans and leave for 6-8 hours. } \\
\text { 2. Add the soaked beans, pearl barley, sliced carrot and onion to the meat broth and cook until almost } \\
\text { tender. } \\
\text { 3. Cut the potato into small cubes, add to the soup season with salt and herbs, and boil for } 10 \text { minutes. } \\
\text { 4. Serve hot with sour cream, sprinkled with dill or parsley for the lunch or dinner. }\end{array}$} \\
\hline
\end{tabular}

Meat is a vital part of the Latvian diet. Lamb, veal, and poultry are eaten, but especially pork in all its forms such as cutlets, roasts, stews, pork chop, jellied meet, sausage, and ham.

Three different examples of standard recipes are given below in Tables 13-15.

Table 13

Standard Recipe 13: Pork and Potato Stew

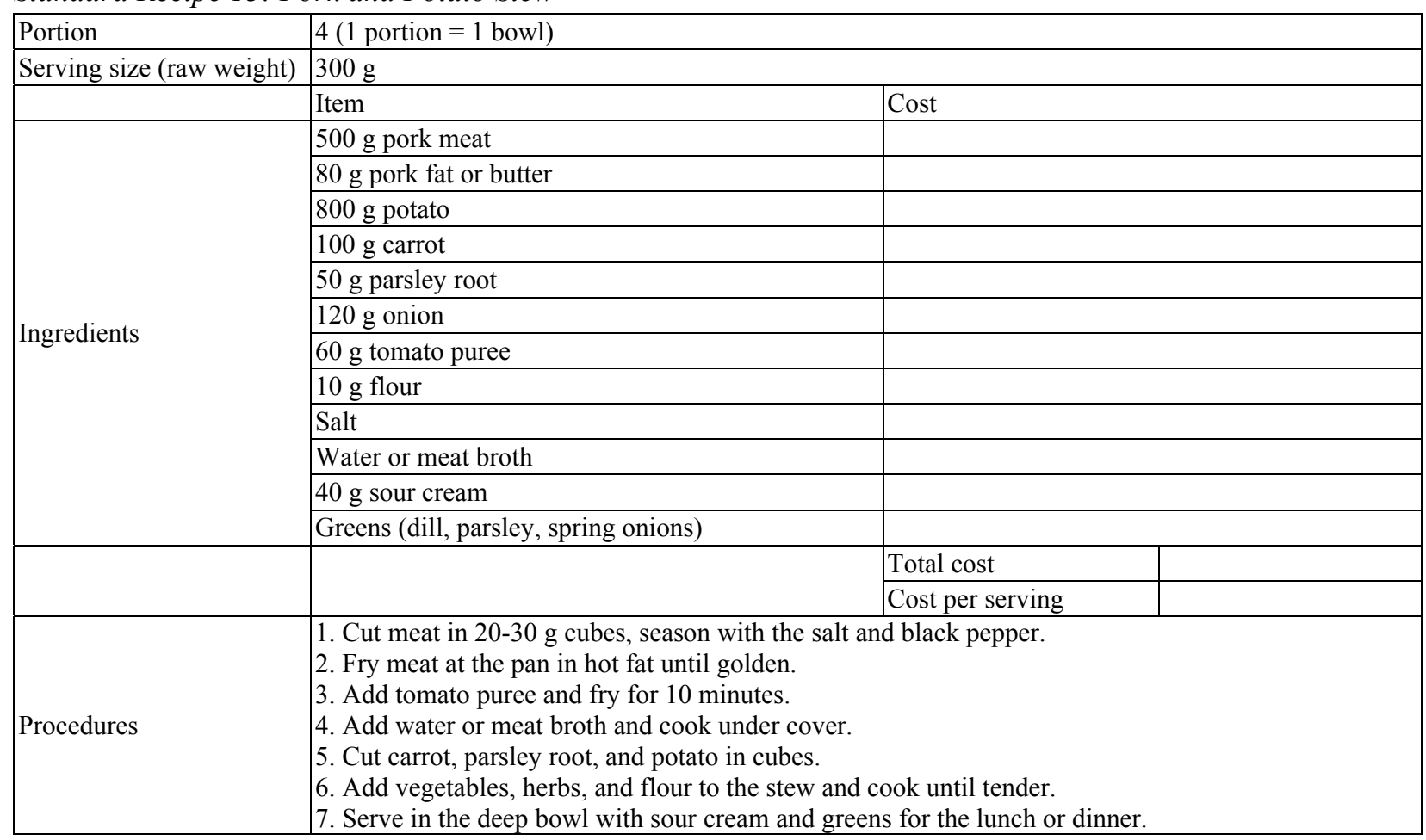


Table 14

Standard Recipe 14: Beef Meatballs

\begin{tabular}{|c|c|c|c|}
\hline Portion & \multicolumn{3}{|l|}{4} \\
\hline \multirow[t]{2}{*}{ Serving size (raw weight) } & \multicolumn{3}{|l|}{2 peaces } \\
\hline & Item & Cost & \\
\hline \multirow{10}{*}{ Ingredients } & $400 \mathrm{~g}$ meat & & \\
\hline & $40 \mathrm{~g}$ white bread & & \\
\hline & 2 eggs & & \\
\hline & Milk or water & & \\
\hline & Salt & & \\
\hline & Pepper & & \\
\hline & Spices & & \\
\hline & $50 \mathrm{~g}$ onion & & \\
\hline & $40 \mathrm{~g}$ bread crumbs & & \\
\hline & Butter for frying & & \\
\hline & & Total cost & \\
\hline & & Cost per serving & \\
\hline Procedures & \multicolumn{3}{|c|}{$\begin{array}{l}\text { 1. Cut meat and mince it. } \\
\text { 2. Soak bread in milk. } \\
\text { 3. Cut and fry onion. } \\
\text { 4. Put all the ingredients in the chopper. } \\
\text { 5. Add salt, pepper, eggs, and milk from the soaked bread and mash well. } \\
\text { 6. Make nice meatballs and roll them. } \\
\text { 7. Fry the meatballs in the hot fat or butter from both sides golden brown. } \\
\text { 8. At the end, put all the meatballs into the oven for a few minutes. } \\
\text { 9. Serve meatballs hot with the boiled or fried potatoes, vegetables, barley, or potato porridge or other } \\
\text { side dishes. } \\
\text { 10. Instead of beef, pork is usually used. }\end{array}$} \\
\hline
\end{tabular}

Table 15

Standard Recipe 15: Chicken Liver Pâté

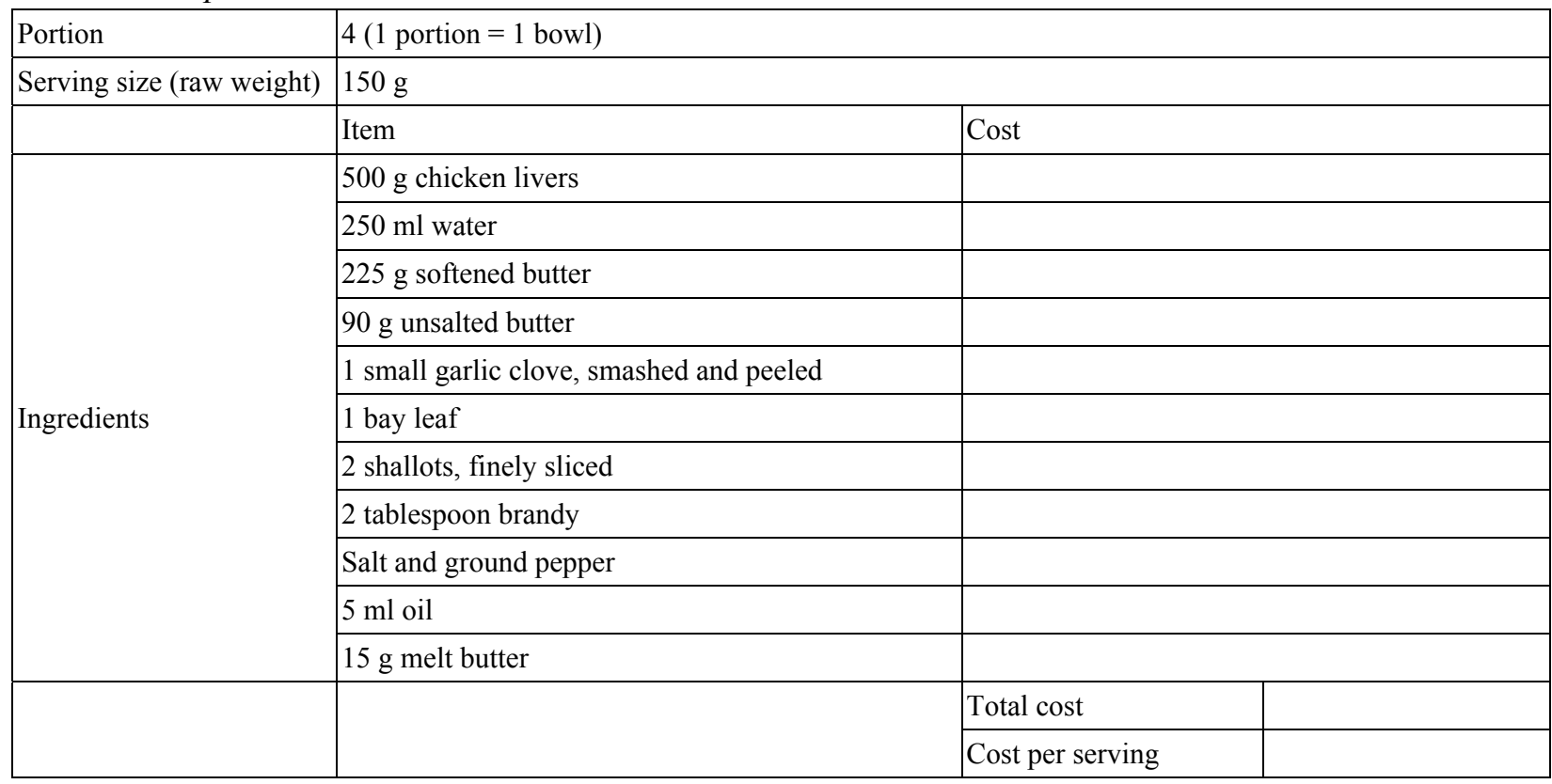


(Table 15 continued)

\begin{tabular}{|l|l|}
\hline \multirow{5}{*}{ Procedures } & 1. Put the oil in deep frying pan and heat over a medium heat. \\
2. Add the shallots and garlic and cook for 2-3 minutes or until began to soften. \\
3. Add the chicken livers, the water, bay leaf, and salt and bring to the boil. \\
4. Cover, reduce the heat, and cook for 15 minutes or until livers become tender. \\
5. Remove from the heat and let stand covered for five minutes. \\
6. Transfer the livers, onion, and garlic to a food processor and process until smooth. \\
7. Add the butter, 2 tablespoon at a time, until incorporated. \\
8. Add the brandy, season with salt and pepper and process until completely smooth. \\
9. Spoon into a ceramic dish and smooth the surface. \\
10. Melt the unsalted butter over the medium heat and pour over the pâté. \\
11. Cover with plastic wrap and chill before serving. \\
12. Serve on a toast. \\
13. Decorate with the slice of lemon.
\end{tabular}

Typical food for Latvians is a different porridge which is made of cereals, legumes, and potatoes. Barley, groats, beans, peas, and lentil porridges provide an important dietary supplement in autumn and winter and were everyday meals for Latvia's long century (Korta, 1905; Suta, 1930). The abovementioned products could be mixed in different combinations. Nowadays, potato porridge is not only a typical meal for Latvians, but the traditional barley porridge again takes its place in Latvian menu. The standard barley and potato porridge recipe is given as an example in Table 16.

Table 16

Standard Recipe 16: Barley and Potato Porridge

\begin{tabular}{|c|c|c|}
\hline Portion & \multicolumn{2}{|l|}{$4(1$ portion $=1$ bowl $)$} \\
\hline \multirow[t]{2}{*}{ Serving size (raw weight) } & \multicolumn{2}{|l|}{$200 \mathrm{ml}$} \\
\hline & Item & Cost \\
\hline \multirow{8}{*}{ Ingredients } & $800 \mathrm{~g}$ potato & \\
\hline & $150 \mathrm{~g}$ barley & \\
\hline & 1.21 water & \\
\hline & $200 \mathrm{ml} \mathrm{milk}$ & \\
\hline & $120 \mathrm{~g}$ onion & \\
\hline & $150 \mathrm{~g}$ smoked bacon & \\
\hline & Salt & \\
\hline & Milk & \\
\hline & & Total cost \\
\hline & & Cost per serving \\
\hline Procedures & \multicolumn{2}{|c|}{$\begin{array}{l}\text { 1. Cut potato into slices and boil in the salted water medium ready. } \\
\text { 2. Wash the barley and add to potato. } \\
\text { 3. Add milk and stew stirring occasionally until potato and barley become tender. } \\
\text { 4. Porridge is served with the roasted bacon and onions. } \\
\text { 5. Milk is served as a drink with porridge. }\end{array}$} \\
\hline
\end{tabular}

Latvians love pancakes. In many families, pancake is a Sunday breakfast dish. Pancakes are served with different jam, jelly, honey, sugar, sour cream, and also cheese, salmon, ham, etc.. The most popular are thin big pancakes, small yeast pancakes, and a variety of stuffed pancakes (with cottage cheese, meat, or apples). As one of the most popular pancake recipes at the autumn, the apple pancake recipe is given as an example in Table 17. 
Table 17

Standard Recipe 17: Apple Pancakes

\begin{tabular}{|c|c|c|c|}
\hline Portion & \multicolumn{3}{|l|}{$4(1$ portion $=10 p)$} \\
\hline \multirow{2}{*}{ Serving size (raw weight) } & \multicolumn{3}{|l|}{$100 \mathrm{~g}$} \\
\hline & Item & Cost & \\
\hline \multirow{6}{*}{ Ingredients } & $165 \mathrm{~g}$ wheat flour & & \\
\hline & $150 \mathrm{ml}$ milk & & \\
\hline & 2 eggs & & \\
\hline & 10 g sugar & & \\
\hline & $100 \mathrm{~g}$ apple & & \\
\hline & 1 tablespoon salt & & \\
\hline & & Total cost & \\
\hline & & Cost per serving & \\
\hline Procedures & \multicolumn{3}{|c|}{$\begin{array}{l}\text { 1. Whisk the egg yolks with sugar, add milk, a little salt, and flour and mix well. } \\
\text { 2. Leave to rest for } 20-30 \text { minutes. } \\
\text { 3. Add to the dough with sugar sprinkled grinded or thin sliced apples. } \\
\text { 4. Fold in the whipped egg whites. } \\
\text { 5. To cook, place a heavy frying pan on a high to medium heat and brush the surface with some butter } \\
\text { or olive oil. } \\
\text { 6. With dessert spoon put the dough into the pan and fry the pancakes on both sides until golden brown. } \\
\text { 7. Serve hot with honey, sour cream, red bilberry jam, or any other jam. } \\
\text { 8. Pumpkin can be used instead of apple. }\end{array}$} \\
\hline
\end{tabular}

Milk, fruits, and berry are the most popular ingredients for the preparation of different desserts. One of the most popular Latvian desserts is semolina pudding (Buberts) with the fresh berry or a sweet berry soup (see Table 18). The preparation methods of the Latvian desserts tend to be simple (Breikse, 1935) as shown in Table 19.

Table 18

Standard Recipe 18: Semolina Pudding With Strawberry (Buberts)

\begin{tabular}{|c|c|c|c|}
\hline Portion & \multicolumn{3}{|l|}{$4(1$ portion $=1$ bowl $)$} \\
\hline \multirow[t]{2}{*}{ Serving size (raw weight) } & \multicolumn{3}{|l|}{$150 \mathrm{ml}$} \\
\hline & Item & Cost & \\
\hline \multirow{7}{*}{ Ingredients } & $500 \mathrm{ml} \mathrm{milk}$ & & \\
\hline & $100 \mathrm{~g}$ semolina & & \\
\hline & 3 big eggs & & \\
\hline & 1 vanilla bean & & \\
\hline & 75 g sugar & & \\
\hline & $300 \mathrm{~g}$ strawberries & & \\
\hline & 100 g sugar & & \\
\hline & & Total cost & \\
\hline & & Cost per serving & \\
\hline Procedures & \multicolumn{3}{|c|}{$\begin{array}{l}\text { 1. Boil milk in a pot until hot. } \\
\text { 2. Whisk in the semolina stirring constantly to avoid forming lumps. } \\
\text { 3. Put the egg yolks and sugar into bowl and whisk until light and creamy. } \\
\text { 4. Take the semolina mixture off from the heat and stir in the whisked egg yolks. } \\
\text { 5. Cool slightly }\left(70^{\circ} \mathrm{C}\right) \text {. } \\
\text { 6. Put the egg whites in the bowl and whisk until egg forms soft peaks. } \\
\text { 7. Whisk slowly the egg whites in the semolina mixture. } \\
\text { 8. Cool semolina pudding and serve topped with the blended strawberry. } \\
\text { 9. Blend strawberries with sugar. } \\
\text { 10. Serve semolina pudding with blended strawberries. } \\
\text { 11. Other berries and fruits can be used instead of strawberries. }\end{array}$} \\
\hline
\end{tabular}


Table 19

Standard Recipe 19: Cranberry and Semolina Dessert (Debesmanna)

\begin{tabular}{|c|c|c|c|}
\hline Portion & \multicolumn{3}{|c|}{$4(1$ portion $=1$ bowl $)$} \\
\hline \multirow[t]{2}{*}{ Serving size (raw weight) } & \multicolumn{3}{|l|}{$200 \mathrm{ml}$} \\
\hline & Item & Cost & \\
\hline \multirow{5}{*}{ Ingredients } & $500 \mathrm{~g}$ cranberries & & \\
\hline & 11 water & & \\
\hline & $200 \mathrm{~g}$ sugar & & \\
\hline & 200 g semolina & & \\
\hline & Milk & & \\
\hline & & Total cost & \\
\hline & & Cost per serving & \\
\hline Procedures & \multicolumn{3}{|c|}{$\begin{array}{l}\text { 1. Crush cranberries and put them in a pot, add one litre boiling water, and cook for five minutes. } \\
\text { 2. Pour the water along with the cranberry skins through a sieve. } \\
\text { 3. Pour the liquid back into the pot, add sugar, and boil for a while. } \\
\text { 4. While stirring, slowly add semolina (each time, the amount of semolina has to be adjusted slightly, } \\
\text { as semolina tends to be different). } \\
\text { 5. All together, stir constantly and cook for five minutes on medium heat. } \\
\text { 6. Take it off from the heat and cool. } \\
\text { 7. Whisk it with mixer until the mixture becomes lighter, double or triple. } \\
\text { 8. Serve in deep plate with cool milk. } \\
\text { 9. Other berries and fruits can be used instead of cranberries. }\end{array}$} \\
\hline
\end{tabular}

There is a great choice of homemade biscuits which are popular and eaten in Latvia. Eggs, butter, vanilla, and sugar are the basic ingredients for most of them (Strazdina, 1969). A simple biscuit recipe as an example can be seen in Table 20 .

Table 20

Standard Recipe 20: Butter Biscuits

\begin{tabular}{|c|c|c|c|}
\hline Portion & \multicolumn{3}{|l|}{$1 \mathrm{~kg}$} \\
\hline \multirow[t]{2}{*}{ Serving size (raw weight) } & \multicolumn{3}{|l|}{130 pieces } \\
\hline & Item & Cost & \\
\hline \multirow{5}{*}{ Ingredients } & $500 \mathrm{~g}$ wheat flour & & \\
\hline & $400 \mathrm{~g}$ butter & & \\
\hline & $100 \mathrm{~g}$ powder sugar & & \\
\hline & 3 egg whites & & \\
\hline & $2 \mathrm{~g}$ vanilla sugar & & \\
\hline & & Total cost & \\
\hline & & Cost per serving & \\
\hline Procedures & \multicolumn{3}{|c|}{$\begin{array}{l}\text { 1. Whisk butter, powder sugar, vanilla, and egg whites, and then add flour and mix. } \\
\text { 2. Leave to rest for half an hour. } \\
\text { 3. Squeeze the dough on the backing pan with a pastry bag using a } 7-9 \mathrm{~mm} \text { diameter toothed ending } \\
\text { and make round, longish, or shell form biscuits. } \\
\text { 4. Serve with tea or coffee. }\end{array}$} \\
\hline
\end{tabular}

\section{Conclusion}

Both Turkish and Latvian cuisines have been influenced by geographic location, history, and by the other cultures.

For both Turkish and Latvian cuisine dairy products, meat and vegetables are the basics of the diet. But the Turks do not eat pork for religious reasons. 
For both Turkish and Latvian cuisines, soups and stews are characteristic.

In Turkish and Latvian cuisines, lots of ingredients used for preparation of the dishes are the same, but the combination of ingredients and food preparation technology is different.

Turks are using more different herbs and spices than Latvians do.

As a part of tourism attraction, traditional cuisine has a large potential to become a significant tourism product.

\section{References}

Akman, M., \& Mete, M. (1998). Türk ve Dünya Mutfakları. Pak-Sil LTD. ŞTİ. Yayını No: 002. Konya, Türkiye: Selçuk Üniversitesi Basımevi.

Albayrak, A. (2013). Farklı Milletlerden Turistlerin Türk Mutfağına İlişkin Görüşlerinin Saptanması Üzerine Bir Çalışma. Journal of Yasar University, 8(30), 5049-5063.

Baysal, A., Merdol, K. T., Başoğlu, S., Ciğerim, N., \& Sacır, H. (2013). Samples from Turkish cuisine. Ankara, Turkey: Hatiboğlu Yayınevi.

Bertina, V. (1937). Pavāru grāmata, otrais izdevums (p. 128). Rīga: Atauga.

Beşirli, H. (2010). Yemek, Kültür Ve Kimlik. Millî Folklor Dergisi, 22(87), 159-169.

Bober, P. P. (1999). Art, culture, and cuisine: Ancient and medieval gastronomy (p. 442). Chicago, USA: The University of Chicago Press.

Breikse, K. (1935). Mājturības un virtuves māksla (p. 208). Rīga: Valters un Rapa.

Dumpe, L. (2009). Latviešu tautas èdieni (p. 287). Rīga: Apgāds Zvaigzne.

Hall, C., \& Sharples, L. (2003). The consumption of experiences or the experience of consumption? An introduction to the tourism of taste. In C. M. Hall, L. Sharples, R. Mitchell, N. Macionis, \& B. Cambourne (Eds.), Food tourism around the world: Development, management, and markets (pp. 1- 24). Oxford, UK: Butterworth-Heinemann-Elsevier.

Kesici, M. (2012). Kırsal Turizme Olan Talepte Yöresel Yiyecek ve İçecek Kültürünün Rolü. KMÜ Sosyal ve Ekonomik Araştırmalar Dergisi, 14(23), 33-37.

Korta, M. (1905). Pavāru grāmata (p. 712). Rīga: J. Sicmana Apgādība.

Masilune, N. (2011). Latviešu nacionālie èdieni (p. 229). Rīga: Jumava.

Masilune, N., \& Pasopa, A. (1986). Latviešu èdieni (p. 277). Rīga: Avots.

Pelude, I. (2011). Gadskārtu ēdieni. Latviskās receptes visam gadam (p. 144). Rīga: Apgāds Zvaigzne.

Silina, K. (1935). Tautas virtuve (p. 191). Rīga: Tautas Bibliotēkas Izdevums.

Strazdina, P. (1969). Latviešu ēdieni (p. 521). Rīga: Latvijas Valsts Izdevniecība.

Suta, N. (1930). Pavāru grāmata (p. 227). Rīga: K/S J. Altbergs un B-dri.

Şanlıer, N. (2005). Yerli ve Yabancı Turistlerin Türk Mutfă̆ı Hakkındaki Görüşleri. GÜ, Gazi Eğitim Fakültesi Dergisi, 25(1), 213-227.

Tannahill, R. (1989). Food in history (p. 424). New York, NY: Three Rivers Press.

Timothy, J., \& Boyd, W. (2003). Heritage tourism (p. 327). China: Pearson Education Limited.

Türk, H., \& Şahin, K. (2004). Antakya Geleneksel Yemek Kültürü. Mustafa Kemal Üniversitesi Sosyal Bilimler Enstitüsü Dergisi, $1(2), 1-17$. 